\title{
Photometric and geometrical characteristics of advertising media installed in the road environment
}

\author{
Piotr Tomczuk ${ }^{1, *}$, and Marcin Chrzanowicz ${ }^{2}$ \\ ${ }^{1}$ Warsaw University of Technology, Faculty of Transport, 75 Koszykowa st., 00-662 Warsaw, Poland \\ ${ }^{2}$ Warsaw University of Technology, Faculty of Electrical Engineering, Plac Politechniki 1, 00-661 \\ Warsaw, Poland
}

\begin{abstract}
Advertising media are located in such a way that they are visible to road users and the visual information reaches the driver regardless of whether the media is located in or outside the lane. Road managers have limited possibilities to influence technical parameters of media placed outside the roadway. However, the light emitted from the advertising medium reaching the driver may be subject to limitations. Subject literature indicates the necessity of using emission parameters in relation to technical parameters of media. The current requirements in Poland specify the maximum luminance values of the advertising media. However, a number of other relevant vehicle emission parameters which may degrade the driver's visual perception of the driver's road environment shall not be taken into account. The need to introduce guidelines for the installation of roadside advertising requires the presentation and discussion of specific technical parameters concerning light emission from the advertising medium. In the article have been discussed of emission parameters of advertising media and examples of measurements of individual lighting parameters, which are possible to be registered in field conditions.
\end{abstract}

\section{Introduction}

Advertising has long been an integral part of architecture and urban planning, interfering with public space and its landscape. Often its location is accidental and is based on the pursuit of the owner's economic interests [1-3]. A potential threat to road safety is posed by advertisements placed in the road environment, they are not part of the road infrastructure, however, they are within the driver's field of vision, which may cause the driver's attention to be aroused and focused $[4,5]$.

Advertising seen from the outset is understood in this article as a type of visual information, with a constant or variable content, presented in any form and by any means and on any medium, presenting information about goods, services, events, businesses or organisations located at or outside the place of establishment. These advertisements are divided into the following categories: mode of impact on road traffic participants, emission

\footnotetext{
* Corresponding author: ptomczuk@,wt.pw.edu.pl
} 
properties, legibility of content, visual information content, method of information transmission, form of information transmission, location of advertising media, location of media in the vehicle driver's field of vision $[2,3]$.

There is no method in the legislation of assessing the light parameters of advertising locations [6-9]. The legislator has only specified a number of restrictions. An example is the determination of the minimum distance between the installation of the advertisement and the road edge [8]. It is also important that advertising media do not imitate traffic signs, signals or road safety devices[7,10]. In the case of permanent media connected with the ground, the regulations of the building law must be met.

A significant change in Polish regulations is the Act in connection with the strengthening of landscape protection tools [9]. The Act introduces a technical parameter for the evaluation of advertisements that have been luminated. The maximum permissible luminance values shall be laid down by a regulation of the Minister for Transport. The draft Regulation is currently the subject of a public consultation and the values initially adopted depend on the time of day. For the day, regardless of the location of the advertisement, the maximum luminance value was initially set at $4000\left(\mathrm{~cd} / \mathrm{m}^{2}\right)$, while for the night it was $600\left(\mathrm{~cd} / \mathrm{m}^{2}\right)$ for the built-up area and $400\left(\mathrm{~cd} / \mathrm{m}^{2}\right)$ for the remaining cases [9].

Despite the introduction of regulations [9] allowing to limit the influence of light from advertising media, road managers in Poland do not know what type of advertising media they use and how they affect drivers. The evaluation of the existing situation with regard to light emission from advertising media will make it possible to indicate the threats for the road traffic participants. Studies conducted in Poland [1,11-13] and in a number of countries $[5,14,15]$ demonstrate the validity of using lighting parameters as one of the criteria for assessing the impact of advertising on drivers. The purpose of this Article is to identify the characteristics of light-emitting advertising media installed in locations visible from the road.

\section{Emission parameters of advertising media}

An important issue is to determined the value of emission parameters for advertising media $[1,11,12]$. This involves performing a number of specialist field measurements of individual lighting parameters, which may include $[12,13]$ : luminance of the surface of the advertising medium $L_{A}\left(\mathrm{~cd} / \mathrm{m}^{2}\right)$, luminance of the surrounding area of the advertising medium $L_{B}\left(\mathrm{~cd} / \mathrm{m}^{2}\right)$, contrast of the luminance of the background of the advertising medium (environment) $C$, colour of the advertising medium (chromaticity $\mathrm{x}, \mathrm{y}$ coordinates). In the case of the $E_{v}$ building, the following factors were taken into account: the CIE layout (1931), the luminance of fogging resulting from the observation of the advertising medium $L_{v}\left(\mathrm{~cd} / \mathrm{m}^{2}\right)$, the intensity of lighting on the eye level of the $E_{\text {eye }}$ driver (lx) and the intensity of lighting on the facade of the $E_{v}$ building (lx).

\subsection{Media and background illumination}

The basic parameter of light emission from the surface of the visual information medium is the luminance of the advertising medium. Luminance $L$ (described by equation 1) $[1,11,13]$ expresses the objective expression by the magnitude of the physical luminous intensity of the media surface. The unit of luminance is the candela per square metre of surface area $\left(\mathrm{cd} / \mathrm{m}^{2}\right)$. If the $d S$ surface is a source of radiation with a luminous intensity of $I$, then:

$$
L=\frac{\mathrm{dI}}{\mathrm{dS} \cdot \cos \Theta}
$$

where: 
$d I$ - the light emitted from the surface of the storage medium in the direction of observation (cd),

$d S$ - the cross-sectional area of the radiation beam containing this point $\left(\mathrm{m}^{2}\right)$,

$\Theta$ - the angle between the normal to the surface of this cross-section and the direction of propagation of the radiation beam $\left({ }^{\circ}\right)$.

The luminance measurement can be carried out with classic or matrix luminance meters. Measuring instruments shall have an angle measuring field not exceeding $1\left(^{\circ}\right)$. The size of the measuring field will determine the distance from which the luminance values of the surface to be measured can be measured while maintaining the photometric maximum distance.

When measuring the luminance of visual information media (light emitting advertisements), the following parameters should be determined on the advertising media surface: minimum luminance $L_{A \min }\left(\mathrm{cd} / \mathrm{m}^{2}\right)$, maximum luminance $L_{A \max }\left(\mathrm{cd} / \mathrm{m}^{2}\right)$, average luminance $L_{\text {Aav }}\left(\mathrm{cd} / \mathrm{m}^{2}\right)$.

Determines the maximum luminance for media, including dynamic media (e.g. media, media, etc.). RGB telegrams), is possible by determining the maximum luminance of the visual information surface, namely the maximum value of the brightness of the visual information specified from all possible directions of the vehicle directional observation medium, determined from measurements taken on the measured surface by means of a luminance meter of the measurement field size not exceeding $1 / 10$ of the maximum measured surface area, with the setting of the maximum emission parameters of the visual information surface. The value of maximum luminance should be determined for a static image, examining the advertising surface perpendicular to the geometric axis of the advertising medium. In the case of LED media, as the viewing angle increases, this value decreases, so it is important to determine the actual luminance levels of the driver's direction of observation advertisements related to the directions of vehicle traffic.

Luminance describes the physical properties of a light-emitting or reflecting surface. In addition to the luminance parameters of the media itself, the luminance of the advertising environment in which the media is located should be measured. The following parameters of the advertising medium environment can be determined: $L_{B m i n}$ minimum background luminance $\left(\mathrm{cd} / \mathrm{m}^{2}\right), L_{B \max }$ maximum background luminance $\left(\mathrm{cd} / \mathrm{m}^{2}\right), L_{B a v}$ average background luminance $\left(\mathrm{cd} / \mathrm{m}^{2}\right)$.

\subsection{Contrast of luminance}

The measurement of the luminance of the environment in which the visual media is located is intended to determine the value of the static contrast of the luminance of the surface of the visual media with that of the background. This value is responsible for the perception of the brightness of the object (carrier) by the observer. The darker the environment in which the medium is located, the more intense the sensations of the observer. It is connected with adaptation of the observer to night lighting conditions. Excessive luminance contrast in the driver's field of vision can disturb the driver's perception of road objects.

The Polish regulations do not specify the value of the permissible luminance contrast. This factor was noted in publication [14], where the maximum permissible luminance contrast value of 12 was adopted.

The contrast $C$ of the luminance of the advertising surface with the background [11-13] is the ratio of the luminance difference of the observed object and the background luminance to the background luminance and can be calculated from formula (2):

$$
C=\frac{L_{A m a x}-L_{B a v}}{L_{B a v}}
$$


where:

$C$ - contrast of luminance,

$L_{\text {Amax }}$ - maximum value of luminance of the advertising medium $\left(\mathrm{cd} / \mathrm{m}^{2}\right)$,

$L_{B a v}$ - the average value of the ambient luminance, background of the advertising medium $\left(\mathrm{cd} / \mathrm{m}^{2}\right)$.

\subsection{Colour of the advertising medium}

One of the important light parameters associated with the emission of radiation from the surface of an advertising medium is the colour of the emitted light. There shall be a potential for misrepresenting the driver concerning the colour of light emitted by the advertising medium. In the case of light advertising media located in the vicinity of roads, there is a high risk that the advertising medium will produce colour parameters similar to those emitted by street traffic lights $[7,10]$, in particular by emission media (i.e. RGB telephones and singlecolour LED advertisements). This parameter may affect road safety. It is therefore justified to test the light emission of the advertisement for chromaticity and conformity with the colours of the light-signalling devices as specified in the standards $[7,10,16]$.

The colours of the lamps used for the signalling (except blue, reserved for priority vehicles) shall comply with the chromaticity coordinates shown in the chromaticity diagram (Table 1). Specific colour gamut(s) are areas where there shall be no colour displayed on the advertisement background of the light-signalling device. However, it is difficult to prohibit the use of available colour pallets by advertisers, in particular on screens that allow for practical generation of any colours available for RGB LED technology. This results in the colours of advertising media in the drivers' field of vision being ambiguously interpreted as street signals.

Table 1. Colour coordinates of individual light signals $[7,10,16]$.

\begin{tabular}{|l|c|c|c|c|c|c|c|c|}
\hline \multirow{2}{*}{ Colour } & \multicolumn{2}{|c|}{$\mathbf{1}$} & \multicolumn{2}{|c|}{$\mathbf{2}$} & \multicolumn{2}{|c|}{$\mathbf{3}$} & \multicolumn{2}{|c|}{$\mathbf{4}$} \\
\cline { 2 - 9 } & $\mathbf{x}$ & $\mathbf{y}$ & $\mathbf{x}$ & $\mathbf{y}$ & $\mathbf{x}$ & $\mathbf{y}$ & $\mathbf{x}$ & $\mathbf{y}$ \\
\hline Red & 0,660 & 0,320 & 0,680 & 0,320 & 0,710 & 0,290 & 0,690 & 0,290 \\
\hline Yellow & 0,536 & 0,444 & 0,547 & 0,452 & 0,613 & 0,387 & 0,593 & 0,387 \\
\hline Green & 0,009 & 0,720 & 0,284 & 0,520 & 0,209 & 0,400 & 0,028 & 0,400 \\
\hline Blue & 0,078 & 0,171 & 0,180 & 0,239 & 0,225 & 0,184 & 0,137 & 0,038 \\
\hline
\end{tabular}

\subsection{Veiling Luminance}

The luminance equivalent to Veiling Luminance $[15,17]$ is indirectly related to the illumination value generated on the driver's eyeball. Advertising media installed around the road shall emit a light beam in the direction opposite to that of the traffic and part of it shall be directed towards the eyes of the observer. An equivalent luminance of mist produced in the eye may cause a deterioration of visual perception or a feeling of discomfort. This effect depends on the action of luminaires, light emitting advertisements and other light sources (e.g. motor vehicles) within the driver's direct field of vision. It affects the level and time of adaptation of the eyes of the observer. The equivalent luminance of mist is summed up in the eyeball with the luminance of the image of the observed object on the roadway $[15,17]$. This value changes the luminance of the perceived object and the background. The determination of luminance values equivalent to LV fog $[15,17]$ is related to the calculation or measurement of actual conditions, the illumination intensity in the eye plane of the observer and a number of geometric parameters. 
The luminance equivalent to mist [15] can be expressed by the formula (3):

$$
L_{v}=\frac{E_{\text {eye }} \cdot r^{2}}{S^{\prime}} \quad\left[\mathrm{cd} / \mathrm{m}^{2}\right]
$$

Veiling luminance $[10,15]$, determining the LV parameter for the visual information medium requires maintaining the geometry shown in Figure 1:

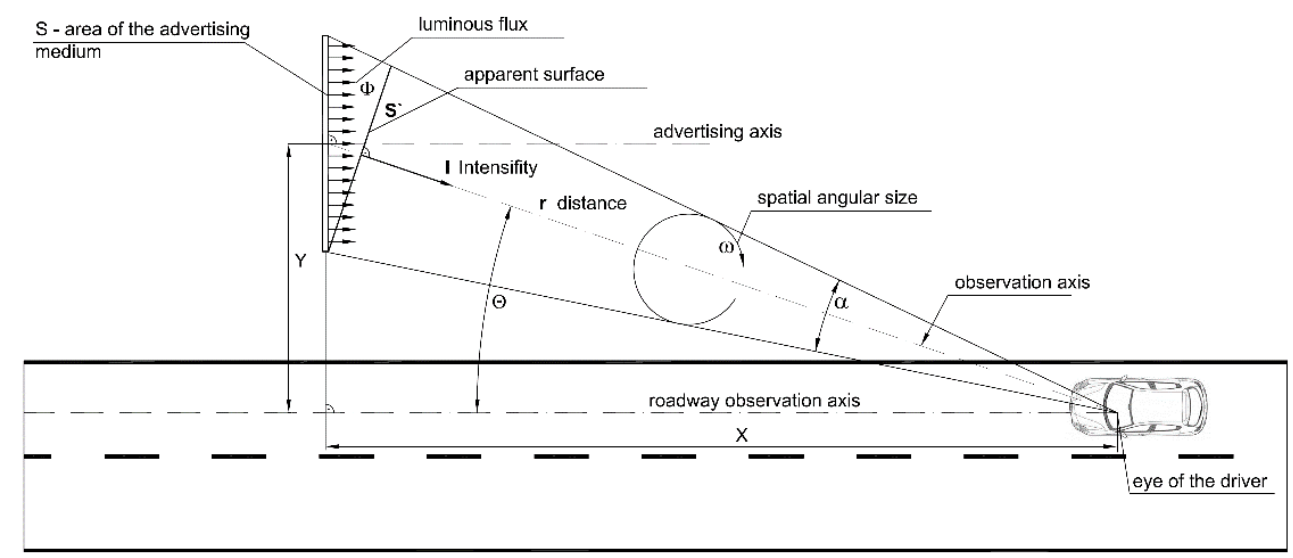

Fig. 1. Measurement geometry for advertising media to determine luminance equivalent to haze. Source: Own calculations based on [15].

The IESNA report [17] indicates limit values for the eye light intensity parameter (tab. 2) depending on the media location area. The report recommends the use of advertising media with emission parameters not higher than those from the E2 area.

Table 2. Limit values for driver's eye illumination [17].

\begin{tabular}{|c|l|c|}
\hline Zone & \multicolumn{1}{|c|}{ Characterisation } & $\begin{array}{c}\text { Lighting limit on the } \\
\text { eyeball } \\
\boldsymbol{E}_{\text {eye }}(\mathbf{l x})\end{array}$ \\
\hline E1 & $\begin{array}{l}\text { Indicates completely dark areas such as national parks or } \\
\text { protected areas. }\end{array}$ & 1.0 \\
\hline E2 & $\begin{array}{l}\text { Designates zones with low luminosity, such as industrial } \\
\text { sites or rural residential areas }\end{array}$ & $\mathbf{3 . 0}$ \\
\hline E3 & $\begin{array}{l}\text { Means zones of medium brightness, such as industrial sites or } \\
\text { suburban residential areas }\end{array}$ & 8.0 \\
\hline E4 & $\begin{array}{l}\text { Designates high brightness zones such as city centres and } \\
\text { commercial zones. }\end{array}$ & 15.0 \\
\hline
\end{tabular}

\subsection{Light pollution}

One of the further aspect of light emission from the surface of advertising media is the problem of reducing the emission of interfering light, described in literature as polluting light, which can create physiological and environmental problems for the environment and people [18]. In the case of light emission from advertising media located in residential areas, it is possible to speak about intrusive light influencing the discomfort of residents, distraction, generate health problems or worsen the perception of observers, including drivers. Environmental pollution by light from advertising media is the emission of light into the upper half of the space, towards the sky, or the emission of light towards the facades of buildings and windows of rooms where people are present. In order to minimize nuisance to 
people, plants and animals, it is aimed at limiting intrusive light emission by introducing recommendations and legal restrictions for outdoor lighting [17], assuming the requirements as in Table 3.

Table 3. Lighting requirements for intrusive outdoor lighting installations [17].

\begin{tabular}{|c|c|c|c|c|c|c|c|}
\hline \multirow{3}{*}{$\begin{array}{c}\text { Envi } \\
\text { ronm } \\
\text { ental } \\
\text { zone }\end{array}$} & \multirow{2}{*}{\multicolumn{2}{|c|}{$\begin{array}{c}\begin{array}{c}\text { Light on immovable } \\
\text { property }\end{array} \\
E_{\text {vertical }}(\mathrm{lx}) \\
\end{array}$}} & \multirow{2}{*}{\multicolumn{2}{|c|}{$\begin{array}{c}\text { The luminous } \\
\text { intensity of the } \\
\text { luminaire }\end{array}$}} & \multirow{2}{*}{$\begin{array}{c}\begin{array}{c}\text { Light } \\
\text { emitted } \\
\text { upwards }\end{array} \\
U L R(\%) \\
\end{array}$} & \multicolumn{2}{|c|}{ Luminance } \\
\hline & & & & & & $L_{b}\left(\mathrm{~cd} / \mathrm{m}^{2}\right)$ & $L_{s}\left(\mathrm{~cd} / \mathrm{m}^{2}\right)$ \\
\hline & $\begin{array}{l}\text { before the } \\
\text { dimming } \\
\text { time*) }\end{array}$ & $\begin{array}{l}\text { after the } \\
\text { dimmin } \\
\text { g time }\end{array}$ & $\begin{array}{l}\text { before } \\
\text { the } \\
\text { dimming } \\
\text { time }\end{array}$ & $\begin{array}{l}\text { after the } \\
\text { dimmin } \\
\text { g time }\end{array}$ & - & $\begin{array}{l}\text { façade of } \\
\text { the } \\
\text { building }\end{array}$ & signs \\
\hline E1 & 2 & 0 & 2500 & 0 & 0 & 0 & 50 \\
\hline$E 2$ & 5 & 1 & 7500 & 500 & 0.05 & 5 & 400 \\
\hline E3 & 10 & 2 & 10000 & 1000 & 0.15 & 10 & 800 \\
\hline$E 4$ & 25 & 5 & 25000 & 2500 & 0.25 & 25 & 1000 \\
\hline
\end{tabular}

*) in the absence of a time limit, the higher values shall not be exceeded and the lower values shall be commissioned as the preferred limits.

$\mathrm{E} 1 \div \mathrm{E} 4$ - zones as in table 2 .

\section{Summary}

The regulations have been introduced in Poland provide for limiting the luminance of advertisements to $600\left(\mathrm{~cd} / \mathrm{m}^{2}\right)$ at night in a built-up area and $4000\left(\mathrm{~cd} / \mathrm{m}^{2}\right)$ during the day, regardless of their location [8]. However, even with these limited luminance values, in late night hours in dark environments, low emission advertisements can be a threat to drivers by producing high luminance contrast values in the driver's field of vision.

The article showed that apart from the maximum luminance value, there are a number of parameters describing the emission from the advertising medium located in the road environment. The lighting properties identified and presented in the article may be the basis for conducting field research on various types of advertising media installed in the road environment and for creating technical requirements that will be enforced against advertisers during the process of granting consent for the location of a new visual information medium and at the stage of inspection of existing media.

An important task is to implement a uniform measurement procedure necessary for a correct and comparable assessment of the impact of light from advertising media installed in the road environment. The recommendations should indicate the values of light parameters and the method of measurement, taking into account the observation of the advertising plane from the driver's position.

Issues presented in this article are the subject of research and analysis in a project carried out by the Faculty of Transport of the Warsaw University of Technology entitled: The impact of advertisements on the level of road traffic safety, contract number: DZP/RID-I-33/4/NCBR/2016 (Registration of Road Innovation), financed by the National Centre for Research and Development and the General Directorate for National Roads and Motorways.

\section{References}

1. K. Domke, M. Zalesińska, Wielkoformatowe elektroniczne reklamy a bezpieczeństwo użytkowników ruchu drogowego, Logistyka. 3 pp. 1351-1361 (2014)

2. M. Glicz, K. Jamroz, T. Mackun, Aktualny stan prawny w zakresie reklam widzianych 
z drogi i rekomendacje do zmian, Transp. Miej. i Reg. 12 pp. 9-15 (2013)

3. T. Mackun, K. Jamroz, J. Żukowska, J. Rychlewska, Zagrożenia dla uczestników ruchu drogowego stwarzane przez reklamy widziane z drogi, Drogownictwo. 4-5 pp. 134141 (2015)

4. S. Speirs, A. Winmill, T. Kazi, The Impact of Roadside Advertising on Driver Distraction: Final Report (WSP Development and Transportation, Basingstoke, 2008)

5. M.W. Tantala, P.J. Tantala, An examination of the relationship between advertising signs and traffic safety, in: 84th Annu. Meet. Transp. Res. Board, (TRB, Washington D.C., 2005)

6. Act of 30 August 2012 Road Traffic Regulation, OJ 2012, pos. 1137 (Poland, 2012)

7. Detailed technical conditions for road signs and signals as well as road safety devices and conditions for their placement on roads. OJ No. 220, Pos. 2181 of 23 December 2003 (Poland, 2003)

8. Act of 21 March 1985 on Public Roads. OJ 2013 pos. 260 (Poland, 2013)

9. Act of 24 April 2015 amending certain acts on strengthening the tools for landscape protection, OJ 2015 Pos. 774 (Poland, 2015)

10. PN-EN 12368:2015-07, Traffic control equipment - signal heads (2015)

11. M. Chrzanowicz, P. Tomczuk, P. Jaskowski, Methodology of Measuring the luminance surface advertisting media which emits lights, Pr. Nauk. Politech. Warsz. Transp. 118 pp. 49-60 (2017)

12. M. Chrzanowicz, P. Tomczuk, Research on the parameters of light emitting advertising media, MATEC Web Conf. 122 pp. $03002 \quad$ (2017). doi:10.1051/matecconf/201712203002

13. P. Tomczuk, P. Jaskowski, Pomiary luminancji wybranych reklam usytuowanych w pasie drogowym, Pr. Nauk. Politech. Warsz. Transp. pp. 95-107 (2015)

14. Deparment of Transport United Arab Emirates, Roadside advertising manual, Document No: AD-R-03 First Edition (Abu Dhabi, 2013)

15. PN-EN 13201-3:2016-03, Road lighting - Part 3: Calculation of lighting parameters, (2016)

16. ISO 3864-4:2011, Graphical symbols — Safety colours and safety signs - Part 4: Colorimetric and photometric properties of safety sign materials (2011)

17. IESNA, TM-11-00, Light Trespass: Research, Results and Recommendations (New York, USA, 2000)

18. A. Niemierzycka, K. Tomczuk, M. Mikicin, A. Zdrodowska, G. Orzechowski, M. Kowalczyk, Examinations of the methods used to power supply of different light sources and their effect on bioelectrical brain activity, Neurol. Neurochir. Pol. 52 pp. 505-513 (2018). doi:10.1016/j.pjnns.2018.02.007 